\title{
DETECTION OF ANTIBIOTICS RESISTANCE GENES IN STAPHYLOCOCCUS AUREUS ISOLATED FROM POULTRY FARMS
}

\author{
OMAR AMEN ' ABEER G. HUSSEIN ${ }^{r}$; ASHGAN M. SAYED ${ }^{r}$ and RAGAB S. IBRAHIM \\ 'Department of Poultry Diseases, Faculty of Veterinary Medicine, Assiut University, Egypt. \\ r Poultry Diseases, Animal Health Research Instiute, Assiut Regional Laboratory.
}

Received: 6 August 2019; Accepted: 8 September 2019

\begin{abstract}
Poultry industry in Egypt was subjected to various problems one of them was the early chick mortalities that cause great economic losses and its investigation is the request of many poultry scientists and men. In poultry staphylococci, including Staphylococcus aureus are known to cause various diseases from acute septicemia to chronic osteomyelitis. Two hundred and sixty samples of chickens, ducks and turkeys were collected from different poultry farms. A survey on Staphylococcal infection among chickens, ducks and turkeys was carried out. It was found that out of 260 infected and dead chickens, ducks and turkeys suspected to be infected with Staphylococcosis, 54 cases $(20.76 \%)$ revealed Staphylococcus micro-organisms. The isolated strains were typed as: Staphylococcus aureus $(74.07 \%)$, Staphylococcus epidermidis (14.8\%) and Staphylococcus saprophyticus $(11 \%)$. The results of sensitivity biogram revealed that $S$. aureus were highly sensitive to Amoxicillin, Ampicillin, Ciprofloxacine, Enrofloxacine and lincomycin and resistant to Erythromycin, Streptomycine and Chloramphenicol. The results of MIC of 6 representative coagulase positive Staphylococci isolates against 6 selected antibiotics commonly used in poultry farms showed that $100 \%$ of isolates were sensitive to amoxicillin, enrofloxacin, ciprofloxacin and oxytetracyclin, while $100 \%$ of 6 isolates were resistant to streptomycin and lincomycin. The incidence of isolation of Staphylococci from the internal organs of examined birds and from unabsorbed yolk sac, joints, liver, intestinal content and heart blood was 36.3\%, 20\%, 19.2\%, $17.3 \%$ and $16.9 \%$ respectively. Ten of each detected isolates were examined by cPCR for resistance genes blaZ and aac(6') aph (2'). The isolates harbored these resistance genes with percentage of $100 \%$ for S. aureus. In experiment, the pathogenicity of the isolated strains of $S$. aureus for 7 day- old chicks was studied. S. aureus injected subcutaneously, oral and intranasal caused death of $100 \%, 100 \%$ and $26.7 \%$ of the used chicks respectively.
\end{abstract}

Key words: Staphylococcus aureus, MIC, cPCR, blaZ and aac (6') aph (2") genes resistance.

\section{INTRODUCTION}

Constant increase in daily growth, especially in broiler chicks, makes the length of the fattening period shorter, and today's birds eat less and produce more. To achieve this, the first few days of a chick's life are important because this is the basis that laid for optimum growth and health. Staphylococcus aureus (S. aureus) is receiving wide spread attention, due to multi-resistant strains, diminishing the usefulness of antibiotics in human and animal medicine and, thereby limiting therapeutic options. Staphylococcal infections were a worldwide problem in chicken and turkey, and cause economic losses due to decrease of egg production and weight gain (Adayel, 2005). Out of 120 isolates, $77(64.1 \%)$ Staphylococcal strains were recovered from diseased and dead chickens

Corresponding author: Dr. Abeer G. Hussein E-mail address: dr_abeergamal@yahoo.com Present address: Poultry Diseases, Animal Health Research Instiute, Assiut Regional Laboratory
(Aml and Samah, 2014). Pesavento et al. (2007) observed that $23.8 \%$ occurrence of coagulase positive $S$. aureus from poultry sample analysed during a oneyear survey in Italy. Suleiman et al. (2013) recorded that $S$. aureus is associated with many clinical syndromes including tenosynovitis, omphalitis, femoral head necrosis, infected hock and stifle joints secondary to coccidiosis and "bumblefoot". Abdellatif et al. (2018) mentioned that (7.5\%) occurrence of $S$. aureus was collected from 30 flocks. Popy et. al. (2011) reported that Staphylococcus sp. $(41.4 \%)$ was isolated from trachea and nasal sinuses of chickens and clinical signs of these affected birds were depression, conjunctivitis, frothy oculo-nasal discharge, conjunctivitis, facial oedema, and respiratory rales. Onaolapo et al. (2017) showed that $S$. aureus high resistance was observed against tetracycline, ciprofloxacin, oxacillin and cotrimoxazole while the isolates showed significant susceptibility to cefoxitin, amoxiclav and gentamicin. White et al. (2003) found that $S$. aureus isolates were commonly resistant to tetracycline $\left(40 \% \mathrm{MIC}_{90}>32\right.$ $\mu \mathrm{g} / \mathrm{ml})$, lincomycin $\left(19 \% \mathrm{MIC}_{90}>32 \mu \mathrm{g} / \mathrm{ml}\right)$, 
erythromycin $\left(12 \% \quad \mathrm{MIC}_{90}>8 \quad \mu \mathrm{g} / \mathrm{ml}\right)$, and kanamycin $\left(8 \% \mathrm{MIC}_{90}<128 \mu \mathrm{g} / \mathrm{ml}\right)$ and all S. aureus isolates were susceptible to chloramphenicol, gentamicin, streptomycin, nitrofurantion, linezolid, quinupristin/dalfopristin, vancomycin. Aml et al. (2018) found that the results of MIC showed that $100 \%$ of isolates were resistant to streptomycin, spectinomycin, ampicillin, cefotaxim, trimethoprimsulphamethazole, gentamycin, and methicillin with MIC $>128 \mu \mathrm{g} / \mathrm{mL}$, while $100 \%$ of isolates were sensitive to tylosin, lincomycine, enrofloxacin, ciprofloxacin and oxytetracyclin. Mohammed et al. (2015) mentioned that $S$. aureus strains show resistance to Cephalosporins; Tetracyclines; Macrolides (Erythromycin); Cloramphenicol; Quinolones (Nalidixic acid) and Aminoglycosides (Neomycin, Gentamycin). Abdellatif et al. (2018) found that $(100 \%)$ bla $\mathrm{Z}$ was detected in $S$. aureus while aac(6') aph (2") was detected in $S$. aureus isolates $(80 \%)$. Nabila (1982) made three routes of infection for 3-day old chicks. Staphylococcus aureus injected subcutaneously, oral or by scarification caused death of $100 \%, 100 \%$ and $23.33 \%$ of the used chicks respectively.

This work aims to study the incidence of $S$. aureus in poultry farms, detection of antibiotics resistance genes in the isolates, evaluate the different methods of infection by $S$. aureus divided to 3 groups each one inject by one method (subcutaneously- oralintranasal) and studying the antimicrobial susceptibility and resistance of bacterial isolates by in vitro disc susceptibility and by using minimum inhibitory concentration (MIC).

\section{MATERIALS AND METHODS}

\section{Samples collection:}

A total of 260 samples from diseased and freshly dead chickens, ducks and turkey of different ages and breeds were collected from private farms in Assuit, Sohag and Almnya Governorates, Egypt. Samples were for isolation heart blood, lungs, intestinal contents, liver, spleen, yolk sac and swollen joints of dead and infected birds showing lesions suggestive of Staphylococcal infection. All samples were taken under aseptic conditions.

\section{Isolation and identification:}

The collected samples and swabs were inoculated into nutrient broth and incubated at $37{ }^{\circ} \mathrm{C}$ for $24 \mathrm{~h}$. A loopful of the inoculated broth was subcultured on nutrient agar, blood agar and Baird Parker agar medium and incubated at $37^{\circ} \mathrm{C}$ for $24-48$ hours. Tentatively identified according to morphological features, pigment production, type of haemolysis produced, gram staining, catalase test, coagulase test (in tubes), sugar fermentation tests including mannitol, maltose, xylose and sucrose and characteristic growth on Mannitol salt agar which used as selective as well as differential medium for isolation and identification of Staphylococci according to the methods Quinin et al. (2004).

\section{Antibiotics susceptibility testing:}

The isolated Staphylococci were tested for their antimicrobial susceptibility using the disk diffusion technique on Mueller-Hinton agar (Difco, Sparks, MD). The results were recorded after $24 \mathrm{~h}$ of incubation at $37^{\circ} \mathrm{C}$. The test was performed according to the method described in the guidelines of the Clinical and Laboratory Standards Institute (CLSI-2013). The zone of inhibition of each antibiotic disc was recorded. Amoxicillin; Ax (25 $\mu \mathrm{g} /$ disk $)$ Ampicillin; Am (10 $\mu \mathrm{g} / \mathrm{disk})$, Streptomycine; S (10 $\mu \mathrm{g} /$ disk), Cephalothin; KF (30 $\mu \mathrm{g} /$ disk $), \quad$ Oxytetracycline; $\mathrm{T} \quad(30 \mu \mathrm{g} / \mathrm{disk})$, Erythromycin; E (15 $\mu \mathrm{g} /$ disk), Ciprofloxacine; CIP (5 $\mu \mathrm{g} /$ disk $)$, Chloramphenicol; $\mathrm{C} \quad(30 \mu \mathrm{g} / \mathrm{disk})$, Enrofloxacine; ENR (5 $\mu \mathrm{g} /$ disk) and Lincomycin; MY $(10 \mu \mathrm{g} /$ disk $)$ were also tested.

\section{Determination of minimum inhibitory concentration (MIC):}

MICs of antibiotics were evaluated using the broth microdilution method in Mueller-Hinton broth (MHB) with an initial inoculum of $5 \times 10^{5}$ cells in nontreated polystyrene microtiter plates CC7672-7596; (CytoOne) in accordance with the Clinical and Laboratory Standards Institute (CLSI. 2007). Bacteria were prepared in phosphate-buffered saline (PBS) until a McFarland standard of 0.5 was achieved. The solution was subsequently diluted 1:300 in MuellerHinton broth (MHB) to reach a starting inoculum of $5 \times 10^{5}$ colony-forming units (CFU/mL). Bacteria were then transferred to a 96-well microtiter plate. Antibiotics were added (in triplicate) to wells in the first row of the microtiter plate and then serially diluted along the vertical axis. The plate was incubated at $37^{\circ} \mathrm{C}$ for $22-24$ hours before the MIC was determined. MIC was defined as the lowest concentration which inhibited the visible growth of bacteria. To determine the (MIC) for the isolated microorganisms used six of different antimicrobial drugs are (Streptomycin - OxytetracyclineCiprofloxacine- lincomycin- amoxicillinenrofloxacine).

\section{Detection of Antimicrobial Resistance genes for bacterial isolates:}

5.1. Extraction of DNA: A rapid boiling procedure was used to prepare template DNA from bacterial isolates according to Duran et al. (2012). Two to 5 loops of bacteria taken from the Baird Parker agar agar plate were collected and suspended in $200 \mu 1$ of lysis buffer comprised of $1 \%$ Triton X-100, $0.5 \%$ Tween 20, $10 \mathrm{mM}$ Tris- $\mathrm{HCl}$ (pH 8.0), and 1 $\mathrm{mM}$ EDTA. After boiling for $10 \mathrm{~min}$, the suspension was centrifuged for 2 min to sediment bacterial debris. The supernatant was aspirated, and from which $5 \mu$ l was used directly for PCR amplification. 
5.2. Primers: Two pairs of primers were supplied from metabion (Germany) and Biobasic (Canada).
They have specific sequence and amplify specific products

Table 1: Oligonucleotide primers sequences.

\begin{tabular}{|c|c|c|c|c|}
\hline Microorganism & Gene & $\begin{array}{c}\text { Primer sequence } \\
\left(5^{\prime}-3^{\prime}\right) \\
\end{array}$ & $\begin{array}{c}\text { Length of amplified } \\
\text { product }\end{array}$ & Reference \\
\hline \multirow{4}{*}{ Staphylococcus } & \multirow{2}{*}{ blaZ } & ACTTCAACACCTGCTGCTTTC & \multirow{2}{*}{$173 \mathrm{bp}$} & \multirow{4}{*}{$\begin{array}{c}\text { Duran et al., } \\
2012\end{array}$} \\
\hline & & TGACCACTTTTATCAGCAACC & & \\
\hline & \multirow{2}{*}{$\begin{array}{l}\operatorname{aac}\left(6^{\prime}\right) a p h \\
\left(2^{\prime \prime}\right)\end{array}$} & GAAGTACGCAGAAGAGA & \multirow{2}{*}{491 bp } & \\
\hline & & ACATGGCAAGCTCTAGGA & & \\
\hline
\end{tabular}

\section{Experimental infection:}

A total number of 60 one day old baladi chicks were obtained from private farm. Chicks were proved to be free from bacterial pathogens after bacteriological examination. Divided into four groups (15 chicks each) (A, B, C and D). Group (A, B and C) each one inject with $S$. aureus by one method (subcutaneouslyoral- intranasal) about $10^{5}, 5 \times 10^{6}$ and $5 \times 10^{6} \mathrm{CFU} / \mathrm{ml}$ respectively and group D kept as control. The infected chickens were observed twice daily to record their general health condition and to notice any clinical signs. Post mortem examination was performed on chickens which died after infection to record any lesions of the internal organs and bacteriological reisolation.

\section{RESULTS}

Based on the identification methods used in our study, a total of $54(20.76 \%)$ Staphylococcal isolates were recovered from 260 chickens, ducks and turkeys samples. Out of these isolates, as a result of morphological and biochemical tests, 50 isolates were from chickens $(24.75 \%), 2$ strains from ducks $(6.6 \%)$ and 2 strains turkeys $(10.71 \%)$ as noted in table (2). Bacteriological identification revealed that colonies of Staphylococci on Baird Parker agar medium were black, shiny and convex surrounded by clear zone. Also there was a characteristic golden yellow growth on Mannitol salt agar. The Staphylococcal aureus isolates showed beta-heamolysis on blood agar medium, positive coagulase and fermented mannitol, maltose and sucrose but not fermented xylose as shown in table (4).

Microscopic characters were gram positive cocci arranged on clusters. The incidence of isolation of Staphylococci from the internal organs of examined birds and incidence of $S$. aureus in relation to age are summarized in figure (1 and 2). Results of antibiotic Susceptibility profile of 20 staphylococcal strains against 10 antimicrobial agents are noted in table (5).

Table 2: Prevalence rate of isolations recovered from examined birds.

\begin{tabular}{|c|c|c|c|c|c|c|c|c|c|c|c|c|}
\hline & \multicolumn{3}{|c|}{ Chicken } & \multicolumn{3}{|c|}{ Duck } & \multicolumn{3}{|c|}{ Turkey } & \multicolumn{3}{|c|}{ Total } \\
\hline & $\begin{array}{c}\text { No. of } \\
\text { samples }\end{array}$ & $\begin{array}{c}+ \\
\text { ve }\end{array}$ & $\%$ & $\begin{array}{c}\text { No. of } \\
\text { samples }\end{array}$ & $+\mathrm{ve}$ & $\%$ & $\begin{array}{c}\text { No. of } \\
\text { samples }\end{array}$ & $+v e$ & $\%$ & $\begin{array}{c}\text { No. of } \\
\text { samples }\end{array}$ & $+v e$ & $\%$ \\
\hline $\begin{array}{c}\text { Staphylococcal } \\
\text { species }\end{array}$ & 202 & 50 & $24.75 \%$ & 30 & 2 & $6.6 \%$ & 28 & 2 & $10.71 \%$ & 260 & 54 & $20.76 \%$ \\
\hline
\end{tabular}

Table 3: shows distribution of Staphylococcal species isolated from poultry.

\begin{tabular}{ccccc}
\hline & Staph. aureus & $\begin{array}{c}\text { Staph. } \\
\text { epidermidis }\end{array}$ & $\begin{array}{c}\text { Staph. } \\
\text { saprophyticus }\end{array}$ & Total \\
\hline No. of cases & $\mathbf{4 0}$ & $\mathbf{8}$ & $\mathbf{6}$ & $\mathbf{5 4}$ \\
\hline Total \% & $15.4 \%$ & $3.07 \%$ & $2.3 \%$ & $20.76 \%$ \\
\hline
\end{tabular}

Table 4: Biochemical and fermentation reactions of suspected Staphylococci isolated from poultry.

\begin{tabular}{ccccc}
\hline & & Staph. aureus & Staph. epidermidis & Staph. saprophyticus \\
\hline \multicolumn{2}{c}{ haemolysis on blood agar } & $+\mathrm{ve}$ & $-\mathrm{ve}$ & $-\mathrm{ve}$ \\
\hline \multicolumn{2}{c}{ Coagulase production test } & +ve & $-\mathrm{ve}$ & $-\mathrm{ve}$ \\
\hline \multirow{2}{*}{$\begin{array}{c}\text { Acid } \\
\text { production } \\
\text { from }\end{array}$} & mannitol & $+\mathrm{ve}$ & $-\mathrm{ve}$ & $+\mathrm{ve}$ or - ve \\
\cline { 2 - 5 } & maltose & $+\mathrm{ve}$ & $+\mathrm{ve}$ & $+\mathrm{ve}$ \\
\cline { 2 - 5 } & sucrose & $+\mathrm{ve}$ & $+\mathrm{ve}$ & $+\mathrm{ve}$ \\
\cline { 2 - 5 } & xylose & $-\mathrm{ve}$ & $-\mathrm{ve}$ & $-\mathrm{ve}$ \\
\hline
\end{tabular}




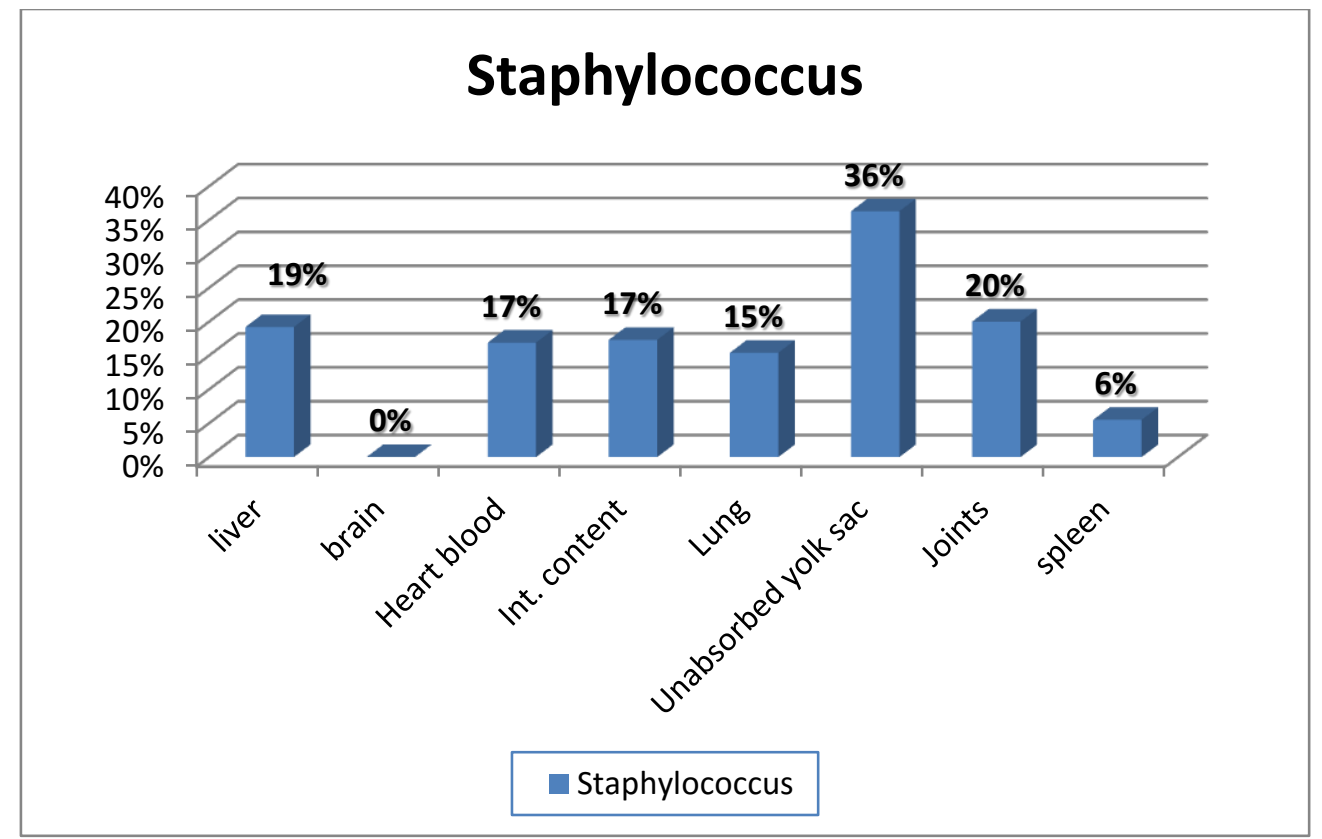

Figure (1): The incidence of Staphylococcus in different organs of examined Chicken, Duck and Turkey

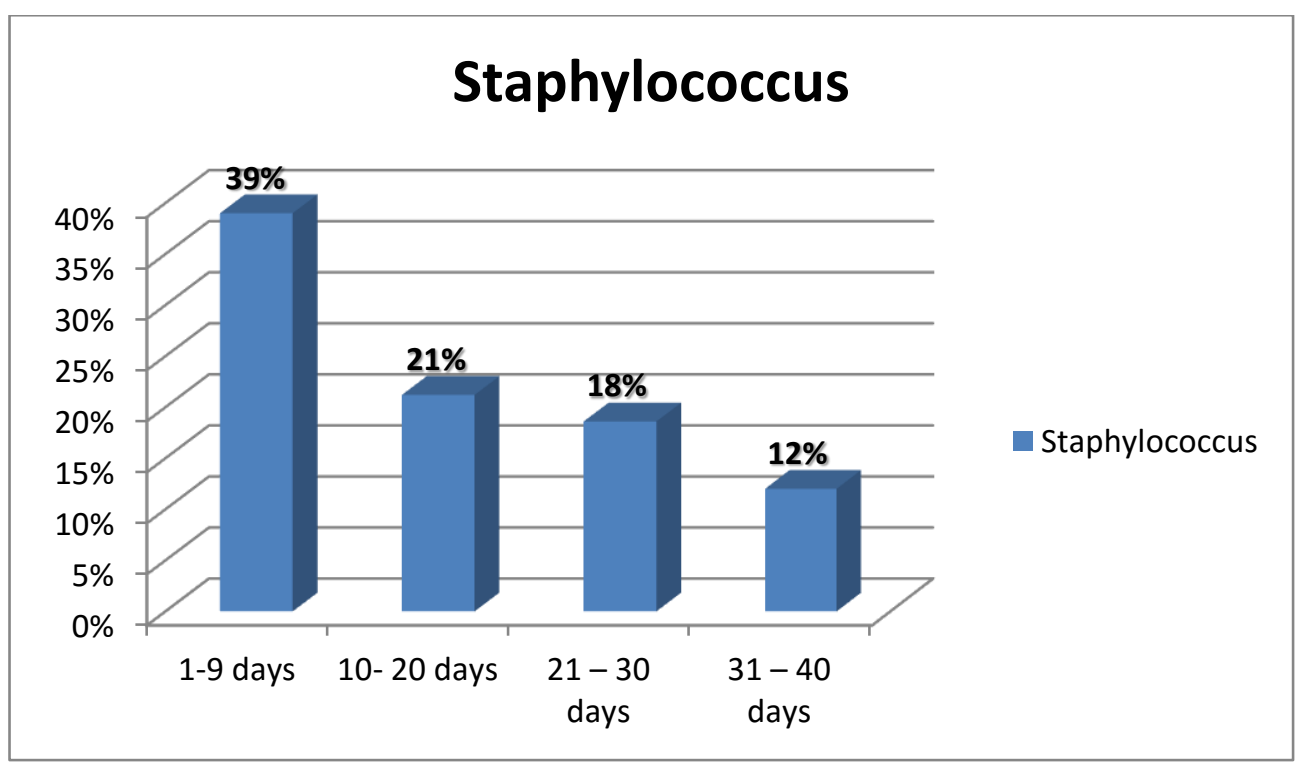

Figure (2): Total incidence of Staphylococcus infection in relation to age.

Table 5: Susceptibility testing of Staphylococcus.

\begin{tabular}{ccccccc}
\hline \multirow{2}{*}{ Antimicrobial agent } & \multirow{2}{*}{$\begin{array}{c}\text { Disk } \\
\text { potency }(\mu \mathrm{g})\end{array}$} & \multirow{2}{*}{ No. of isolates } & \multicolumn{2}{c}{ Sensitive isolates } & \multicolumn{2}{c}{ resistant isolates } \\
\cline { 3 - 7 } & $\left(\mathbf{A x}_{25}\right)$ & 20 & Number & $\%$ & Number & $\%$ \\
\hline Amoxicillin & $\left(\mathbf{A m}_{10}\right)$ & 20 & 20 & 100 & 0 & 0 \\
\hline Ampicillin & $\left(\mathbf{S}_{10}\right)$ & 20 & 5 & 25 & 15 & $\mathbf{0}$ \\
\hline Streptomycine & $\left(\mathbf{K F}_{30}\right)$ & 20 & 0 & 0 & 20 & 100 \\
\hline Cephalothin & $\left(\mathbf{T}_{30}\right)$ & 20 & 12 & 60 & 8 & 40 \\
\hline Oxytetracycline & $\left(\mathbf{E}_{15}\right)$ & 20 & 0 & 0 & 20 & 100 \\
\hline Erythromycin & $\left(\mathbf{C I P}_{5}\right)$ & 20 & 18 & 90 & 2 & 10 \\
\hline Ciprofloxacine & $\left(\mathbf{C}_{30}\right)$ & 20 & 5 & 25 & 15 & 75 \\
\hline Chloramphenicol & $\left(\mathbf{E N R}_{5}\right)$ & 20 & 20 & 100 & 0 & 0 \\
\hline Enrofloxacine & $\left(\mathbf{M Y}_{10}\right)$ & 20 & 19 & 95 & 1 & 5 \\
\hline Lincomycin & & & & & &
\end{tabular}


The results of MIC of 6 representative coagulase positive staphylococci isolates against 6 selected antibiotics commonly used in poultry farms were illustrated in table (6), results showed that $100 \%$ of isolates were sensitive to amoxicillin, enrofloxacin, ciprofloxacin and oxytetracyclin, while $100 \%$ of 6 isolates were resistant to streptomycin and lincomycin.
Genotypic identification of 10 representative coagulase positive Staphylococcus isolates was performed by cPCR assay. Simultaneously, Ten of each detected isolates were examined by cPCR for resistance genes blaZ and $\operatorname{aac}\left(6^{\prime}\right)$ aph (2',). The isolates harbored these resistance genes with percentage of $100 \%$ and $100 \%$ respectively for $S$. aureus respectively in Figure $(3,4)$.

Table 6: Showing results of susceptibility of 6 isolates of Staphylococcus aureus to antibacterial agents.

\begin{tabular}{|c|c|c|c|c|c|c|c|c|c|c|c|c|c|c|}
\hline \multirow{2}{*}{ Antibiotic } & \multicolumn{11}{|c|}{ No. of isolates with MIC $(\mu \mathrm{g} / \mathrm{ml})$ of: } & \multirow{2}{*}{$\begin{array}{c}\text { Break point } \\
\text { of drug } \\
\text { sensitive }\end{array}$} & \multirow{2}{*}{$\begin{array}{c}\text { No. of } \\
\text { sensitive } \\
\text { isolates }\end{array}$} & \multirow{2}{*}{$\begin{array}{c}\% \text { of } \\
\text { sensitive } \\
\text { isolates }\end{array}$} \\
\hline & 0.125 & 0.25 & 0.5 & 1 & 2 & 4 & 8 & 16 & 32 & 64 & 128 & & & \\
\hline Streptomycin & - & & - & - & - & - & - & - & 4 & 2 & - & $0.6-16$ & 0 & $0 \%$ \\
\hline Amoxicillin & - & - & - & - & 4 & 2 & - & - & - & - & - & $0.3-128$ & 6 & $100 \%$ \\
\hline Oxytetracycline & - & - & - & - & - & 5 & - & 1 & - & - & - & $0.6-128$ & 6 & $100 \%$ \\
\hline Lincomycin & - & - & - & - & - & - & 2 & 4 & - & - & - & $1-2$ & 0 & $0 \%$ \\
\hline Ciprofloxacine & 2 & 4 & - & - & - & - & - & - & - & - & - & $0.6-1$ & 6 & $100 \%$ \\
\hline Enrofloxacine & 3 & 3 & - & - & - & - & - & - & - & - & - & $0.5-1$ & 6 & $100 \%$ \\
\hline
\end{tabular}

\section{Experimental infection}

The incubation period varied from 24 hours up to 14 days according to the type of bacteria and the route of infection. The results obtained are shown in table (7 and 8) and in picture (1, 2 and 3). S. aureus injected subcutaneously caused death of all birds (100\%) within 3-5 days post-inoculation. Also, administration of the organism orally caused death of all birds (100\%) within 2-8 days post-inoculation, while intranasal route caused death of only $26.7 \%$. No symptoms or post-mortem findings were observed in control chickens during the 4 week observation period.

Table 7: Respond of chicks to $S$. aureus by various routes of infection.

\begin{tabular}{|c|c|c|c|c|c|c|c|c|c|c|c|c|c|c|c|c|c|c|c|}
\hline \multirow{2}{*}{$\begin{array}{l}\text { Group } \\
\text { No. }\end{array}$} & \multirow{2}{*}{$\begin{array}{l}\text { Subgroup } \\
\text { No. }\end{array}$} & \multirow{2}{*}{$\begin{array}{c}\text { Bacterial } \\
\text { inoculated }\end{array}$} & \multirow{2}{*}{$\begin{array}{l}\text { Route of } \\
\text { infection }\end{array}$} & \multirow{2}{*}{$\begin{array}{l}\text { No. of } \\
\text { inoculated- } \\
\text { chicks }\end{array}$} & \multicolumn{11}{|c|}{$\begin{array}{c}\text { Cumulative death losses at (days after } \\
\text { infection) }\end{array}$} & \multicolumn{4}{|c|}{ Accumulated value } \\
\hline & & & & & 8 & 9 & 10 & 12 & 14 & 15 & 18 & 20 & 22 & 24 & 28 & $\begin{array}{l}\text { No. } \\
\text { Dead }\end{array}$ & $\begin{array}{l}\text { No. } \\
\text { Survived }\end{array}$ & $\begin{array}{l}\text { Mortality } \\
\text { Ratio }\end{array}$ & $\begin{array}{l}\text { Mortality } \\
(\%)\end{array}$ \\
\hline \multirow{3}{*}{ I } & $\mathbf{A}$ & \multirow{3}{*}{$\begin{array}{l}\text { Staph. } \\
\text { aureus }\end{array}$} & $\mathrm{S} / \mathrm{C}$ & 15 & - & - & 5 & 4 & 5 & 1 & - & - & - & - & - & 15 & 0 & $15 / 15$ & $100 \%$ \\
\hline & $\mathbf{B}$ & & orally & 15 & - & 2 & 3 & 5 & 2 & 1 & 2 & - & - & - & - & 15 & $\mathbf{0}$ & $15 / 15$ & $100 \%$ \\
\hline & $\mathbf{C}$ & & Intrasal & 15 & - & - & - & - & 2 & 1 & 1 & - & - & - & - & 4 & 11 & $4 / 15$ & $26.7 \%$ \\
\hline
\end{tabular}

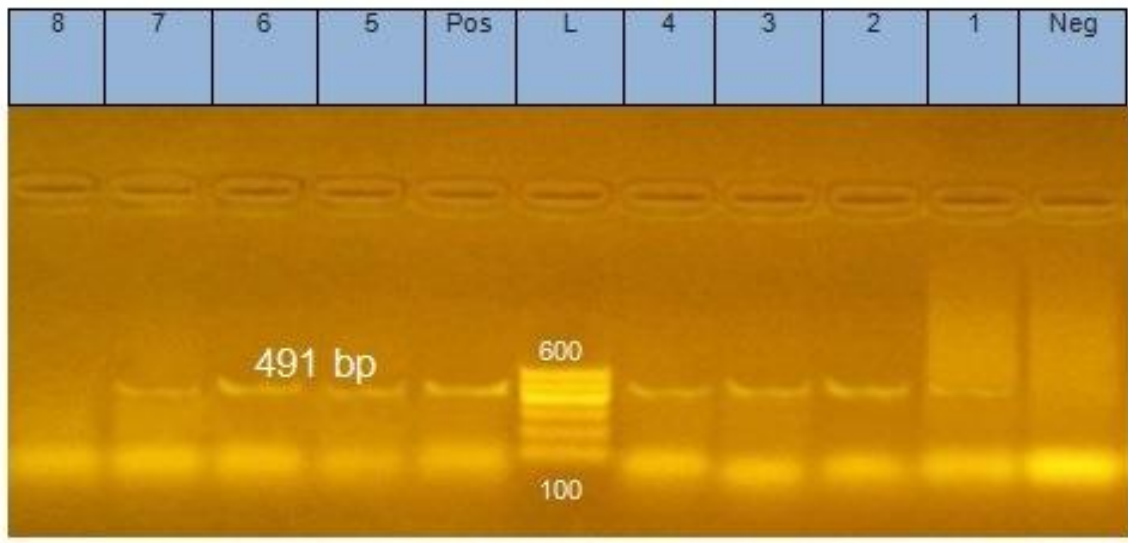

Figure (3): showing result of PCR for resistance gene aac (6') aph (2") for Staphylococcus. 


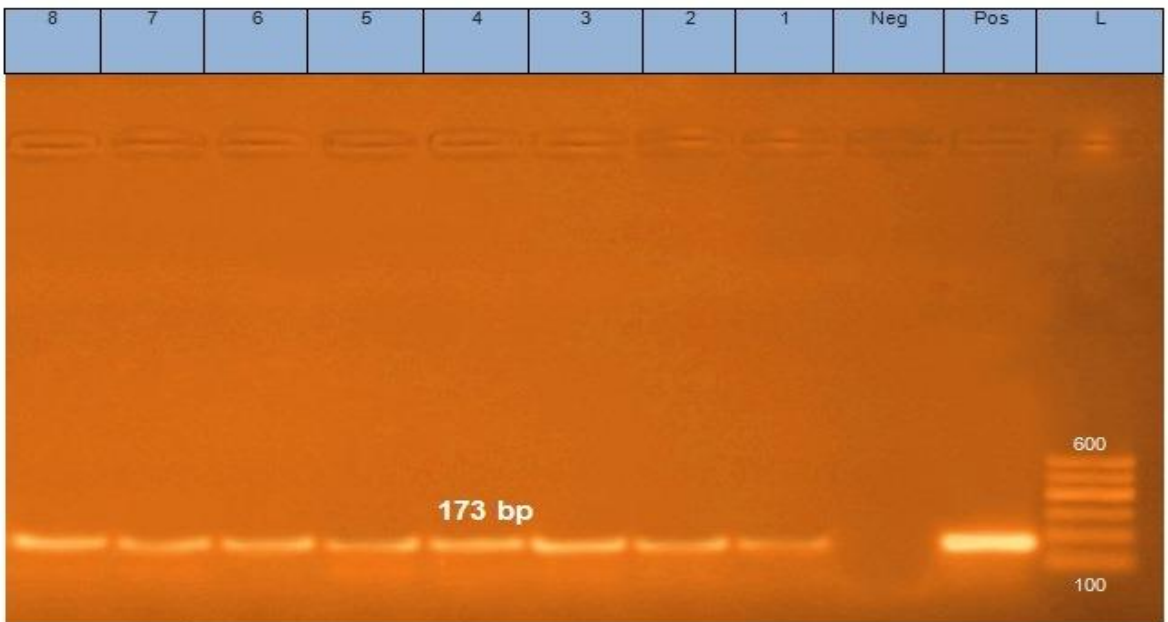

Figure (4): showing result of PCR for resistance gene blaZ for Staphylococcus

Table 8: Show clinical signs and gross lesion of Staphylococcus aureus.

\begin{tabular}{cll}
\hline Staphylococcus aureus & Route of infection & \multicolumn{1}{c}{ Signs } \\
\hline & subcutaneously & $\begin{array}{l}\text { Depression, dropping of wings, dullness, ruffled feathers, } \\
\text { inability to stand, lameness and swelling of joints. }\end{array}$ \\
\cline { 2 - 4 } Clinical signs & Orally & $\begin{array}{l}\text { Orally infected chicks showed similar symptoms. In addition } \\
\text { on, diarrhea was observed. }\end{array}$ \\
\hline Intra nasal & $\begin{array}{l}\text { Nasal infected chicks developed gasping, depression and } \\
\text { dropping of wings. }\end{array}$ \\
\hline \multirow{2}{*}{ The postmortem findings } & $\begin{array}{l}\text { Typical septicemia, congestion and hemorrhages of the } \\
\text { subcutaneous blood vessels, muscles of the breast and thigh, } \\
\text { congestion of the lungs, liver and kidney and caseous masses } \\
\text { in the joints. Meanwhile unabsorbed yolk sac and enteritis } \\
\text { were observed in chickens infected orally. }\end{array}$ \\
\hline
\end{tabular}
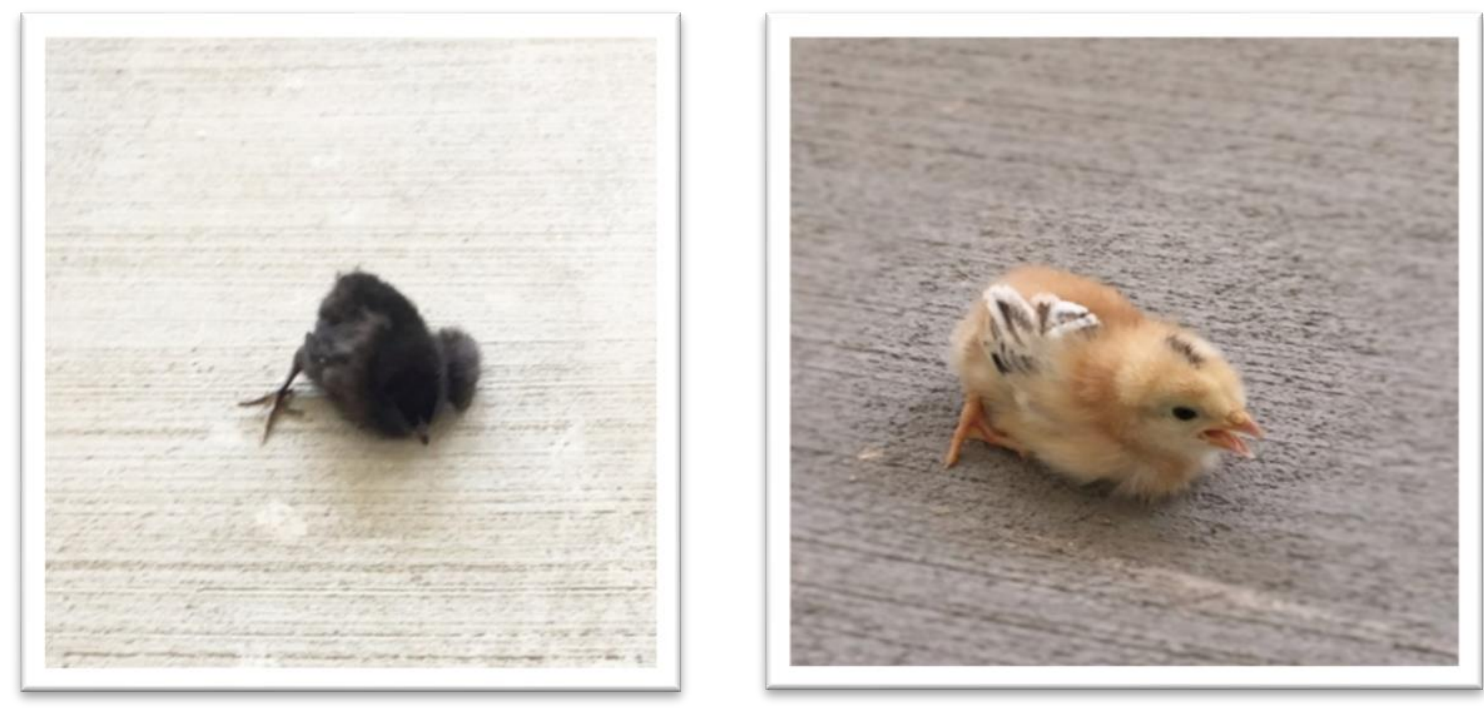

Picture (1): On the left picture show chick inoculated S/C with Staph. aureus and showing depression, dullness, inability to walk and dropping wings. On the right picture show chick inoculated intranasal with $S$. aureus and showing depression, difficult to stand, gasping and dropping of wings. 


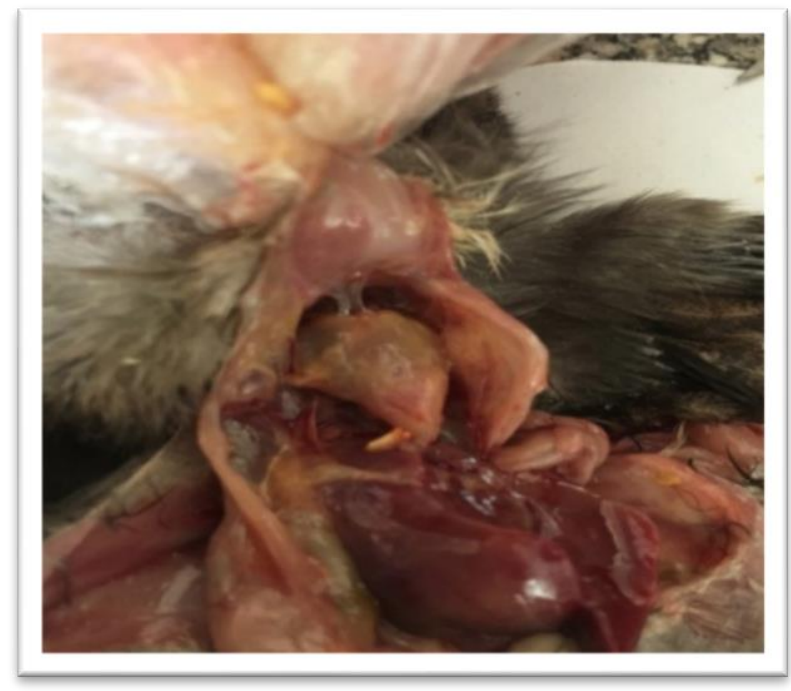

Picture (2): Chick inoculated S/C with Staph. aureus and showing air saculitis and pericarditis, congestion of subcutaneous tissue, congestion and enlargement of the liver.
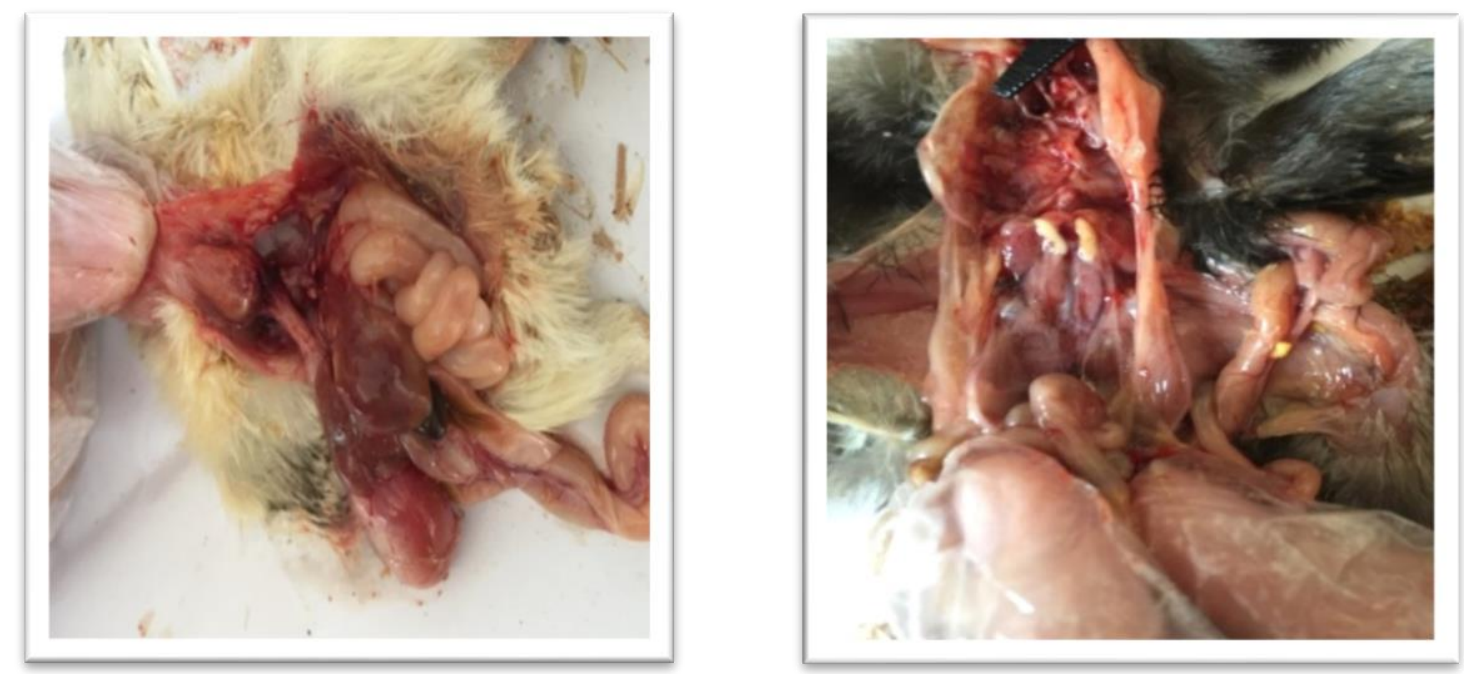

Picture (3): On the left picture show chick inoculated orally with Staph. aureus and showing congestion of subcutaneous tissue, congestion of internal organs of the liver, heart and intestine. On the right picture show chick inoculated intranasal with Staph. aureus and showing congestion of subcutaneous tissue, congestion of internal organs of the lung and kidney.

\section{DISCUSSION}

In recent years, Staphylococcus infections have been considered of importance in the causation of certain problems in intensive poultry farms, extensive investigations have been carried out for nature and incidence of these infections among poultry in Egypt.

The incidence of Staphylococci among chickens, turkeys and ducks was determind. The clinical signs observed in chickens, turkeys and ducks from which staphylococcus micro-organisms could be isolated were: depression, dropping of the wings, dullness, ruffled feathers, inability to stand these results agree with Lowder (2011). On the other hand, Popy et al. (2011) and Onaolapo et al. (2017) showed respiratory symptoms in natural out breaks of staphylococcal infection in fowls, ducks and turkeys. These symptoms were not observed in naturally infected birds examined in the present work.

Post-mortem examination of birds naturally infected with Staphylococci revealed congestion and hypertrophy of liver and spleen, unabsorbed yolk sac and congestion of the breast and thigh muscles. These findings were more or less similar to observations of Popy et al. (2011) recorded that Staphylococcus sp. $(41.4 \%)$ was isolated from chickens and gross lesions of upper respiratory tracts were catarrhal tracheitis and rhinitis.

Staphylococcus micro-organisms with recovery rate $20.76 \%$. These results agree with previous studies reported by Pesavento et al. (2007). In contrast Aml 
and Samah (2014) reported that $64 \%$ Staphylococcal strains were isolated from diseased and dead broiler chickens samples.

S. aureus was the most dominant species recovered (15.4\%), followed by $S$. epidermidis (3.07\%) and $S$. saprophyticus $(2.3 \%)$. These results agree with previous studies reported by Nabila (1982) while Abdellatif et al. (2018) found that $S$. aureus was isolated from $15(7.5 \%)$ cases from 200 broiler samples.

The incidence of isolation of Staphylococci from the internal organs of examined birds from unabsorbed yolk sac, joints, liver, intestinal content and heart blood was $36.3 \%, 20 \%, 19.2 \%, 17.3 \%$ and $16.9 \%$ respectively. These results were less similar to previous studies reported by Nabila (1982).

In the present study, the incidence of Staphylococcal organism was high (39\%) in birds aged 1-9 days, while a lower number of strains were recovered from samples of birds $(21.2 \%)$ in birds aged 10-20 days and (18.6\%) in birds aged 21-30 days.

The sensitivity of isolated Staphylococcus aureus strains to various drugs was studied. It was found that most isolates were highly sensitive to Amoxicillin, Ampicillin, Ciprofloxacine, Enrofloxacine and lincomycin and were resistant to Erythromycin, Streptomycine and Chloramphenicol and similar findings were reported by Emilia (2008) and contradictory to that reported by Jamali et al. (2015) stated that $\mathrm{S}$. aureus resistant to tetracycline, chloramphenicol, and gentamicin but low incidence in case of erythromycin, kanamycin, streptomycin, penicillin $\mathrm{G}$, and oxacillin.

The results of MIC of 6 representative coagulase positive staphylococci isolates against 6 selected antibiotics commonly used in poultry farms showed that $100 \%$ of isolates were sensitive to amoxicillin, enrofloxacin, ciprofloxacin and oxytetracyclin, while $100 \%$ of 6 isolates were resistant to streptomycin and lincomycin. These results were similar to previous studies were observed by Aml et al. (2018).

Ten of each detected isolates were examined by cPCR for resistance genes blaZ and aac (6') aph (2',). The isolates harbored these resistance genes with percentage of $100 \%$ and $100 \%$ respectively for $S$. aureus. These results were similar to previous studies were observed by Abdellatif et al. (2018).

In experiment, the pathogenicity of the isolated strains of Staphylococcus aureus for 7 day- old chicks was studied. Staphylococcus aureus injected subcutaneously, oral and intranasal caused death of $100 \%, 100 \%$ and $26.7 \%$ of the used chicks respectively. Similar findings were reported by Nabila (1982).
Chicks infected subcutaneous with $S$. aureus showed signs of depression, dropping of wings, dullness, ruffled feathers, inability to stand and lameness. Diarrhea was detected only in chicks infected orally. Chicks developed gasping was detected in chicks infected intranasal. Nearly similar findings were reported by (Awan, 1998) and (Lowder, 2011).

Postmortem lesions observed among chicks infected with $S$. aureus were mainly typical of septicemia, congestion and hemorrhages of the subcutaneous blood vessels, muscles of the breast and thigh, liver and kidney and caseous masses in the joints. Meanwhile unabsorbed yolk sac and enteritis were observed in chickens infected orally and congestion of the lungs was observed in chickens infected intranasal. These lesions are similar to those observed by Popy et al. (2011).

In Conclusion, this study confirms that Staphylococcal infection responsible for economic losses and zoonotic importance. The high incidence of antibiotic resistant of $S$. aureus among poultry farms which were detected in our study could mean the antibiotics misuse and abuse especially in farms which will accelerate the development and spreading of antibiotics resistant bacteria not only between chickens but also in the environment or even to the human being. Moreover, the study concluded that the presence of the blaZ and aac (6') aph (2', ) resistance genes bacteria of the isolated strains.

\section{REFRENCES}

Abdellatif Hala, A.; Samy A. Khalil and Abdelhalim Hegazy (2018): Molecular Study on Bacterial Resistance to Antibiotic with Special Reference to Plasmid Curing. Alexandria Journal of Veterinary Sciences, 58 (1): 109119.

Adayel, S.A. (2005): Incidence of staphylococcus aureus causing artheritis of broiler breeders 4th Int. Sc. Conf. Mansoura.

Aml M. Bakheet and Samah F. Darwish (2014): Phenotypic and genotypic detection of methicillin- resistant staphylococcus aureus (mrsa) in broiler chickens. Assiut Vet. Med. J. Vol. 60 No. 143.

Aml M. Bakheet, Omar Amen, Sayed H.AL. Habaty and Samah F. Darwish (2018): Prevalence of Staphylococcus aureus In Broiler Chickens with Special Reference to Beta-Lactam Resistance Genes in the Isolated Strains. Alexandria Journal of Veterinary Sciences, 57 (2): 25-33.

Awan, M.A. (1998): Systemic Bacterial Infections in Broiler Chickens. M.V.Sc. Thesis, Oregon State University.

CLSI, Clinical and Laboratory Standards Institute (2007): Methods for dilution antimicrobial susceptibility tests for bacteria that grow 
aerobically; approved standard M-A7. CLSI, Wayne, PA.

CLSI, Clinical and Laboratory Standards Institute (2013): Performance Standards for Antimicrobial Disk and Dilution Susceptibility Tests for Bacteria isolated from Animal; approved standard- fourth Edition. CLSI document Vet01-A4. Wayne, PA: Clinical and Laboratory Standards Institute; 2013.Vol. 33 No. 7.

Duran, N.; Ozer, B.; Duran, G.G.; Onlen, Y. and Demir, C. (2012): Antibiotic resistance genes \& susceptibility patterns in staphylococci. Indian J Med Res 135, pp 389-396.

Emilia Ciocîrlan (2008): Research on the incubation bacterial microflora. Cercetări Agronomice În Moldova vol. XII, no. 2 (134).

Jamali, H.; Paydar, M.; Radmehr, B.; Ismail, S. and Dadrasnia, A. (2015): Prevalence and antimicrobial resistance of Staphylococcus aureus isolated from raw milk and dairy products. Food Control. J., 54: 383-388.

Lowder, B. (2011): Host-adaptive evolution of Staphylococcus aureus. Ph.d. Thesis. University of Edinburgh.

Mohammed, G.M.O.; HAFEZ, T.A. and ELDahshan, H.A. (2015): prevalence and antimicrobial resistance of staphylococcus aureus isolated from meat and some meat products with detection of resistant genes using PCR. Egypt. J. Agric. Res., 93, 4 (A): 63-79.

Nabila, M.D. (1982): Studies on Staphylococcosis and Streptococcosis in poultry. M.V.Sc. (Poultry diseases).
Onaolapo, J.A.; Igwe, JC.; Bolaji, RO.; Adeshina, GO. and Parom, SK. (2017): Antibiotics Susceptibility Profile of Staphylococcus aureus Isolated from Poultry Birds in Kaduna, Nigeria. J Clin Microbiol Antimicrob 1(1): 1-6.

Pesavento, G.; Ducci, B.; Comodo, N. and Lo Nostro, A. (2007): Antimicrobial resistance profile of Staphylococcus aureus isolated from raw meat: A research for methicillin resistant Staphylococcus aureus (MRSA). Food Control, 18: 196-200.

Popy N.; Asaduzzaman, M.; Miah, M. S.; Siddika, A.; Sufian, M.A. and Hossain, M.M. (2011): Pathological study on the upper respiratory tract infection of chickens and isolation, identification of causal bacteria. The Bangladesh Veterinarian 28 (2): 60-69.

Quinin, P.J.; Carter, M.E.; Markey, B. and Carter, G.R. (2004): Clinical veterinary microbiology printed in Spain by Grafos, S.A. Arte Sobre Pape J.

Suleiman A.; Zaria, L.T.; Grema, H.A. and Ahmadu, P. (2013): Antimicrobial resistant coagulase positive Staphylococcus aureus from chickens in Maiduguri, Nigeria. Sokoto Journal of Veterinary Sciences, Volume 11 (Number 1): 51-55.

White D.G.; Sherry Ayers; John J. Maurer; Stephan G. Thayer and Charles Hofacre (2003): Antimicrobial Susceptibilities of Staphylococcus aureus Isolated from Commercial Broilers in Northeastern Georgia. Avian diseases 47: 203-210.

الكثف عن الجينات المقاومة للمضادات الحيوية في المكورات العنقودية الذهبية المعزولة من مزارع الدواجن

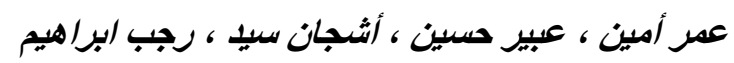

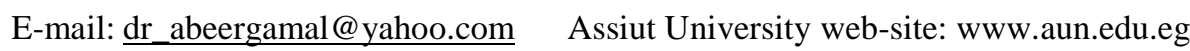

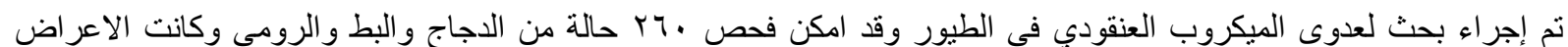

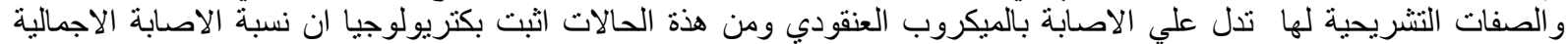

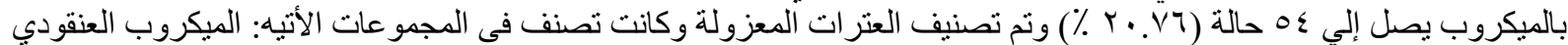

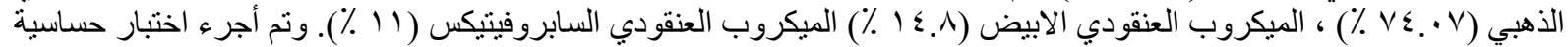

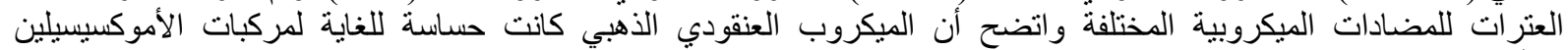

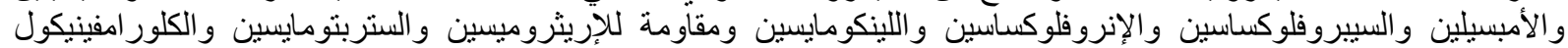

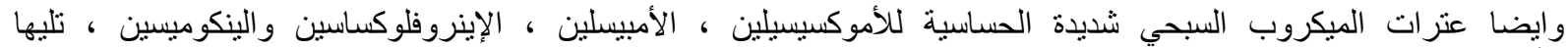

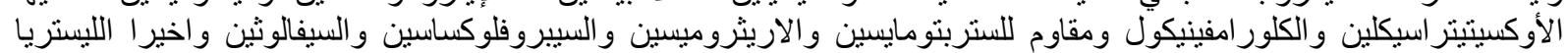

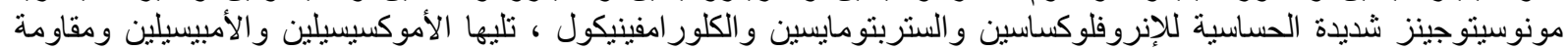

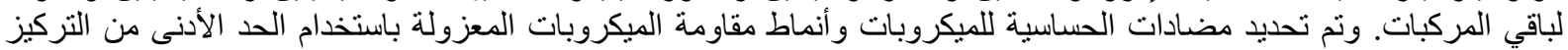

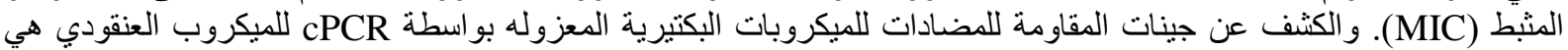

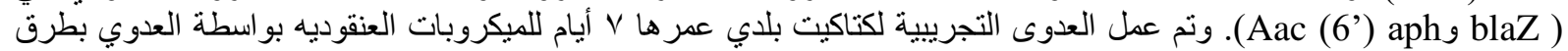

